\title{
Aggressiveness of Typhula ishikariensis Isolates to Cultivars of Bentgrass Species (Agrostis spp.) Under Controlled Environment Conditions
}

\author{
S. W. Chang and T. H. Chang, Department of Plant Pathology, University of Wisconsin, Madison 53706; \\ L. Tredway, Department of Plant Pathology, North Carolina State University, Raleigh 27695; and G. Jung, Depart- \\ ment of Plant Pathology, University of Wisconsin, Madison 53706
}

\begin{abstract}
ABSTACT
Chang, S. W., Chang, T. H., Tredway, L., and Jung, G. 2006. Aggressiveness of Typhula ishikariensis isolates to cultivars of bentgrass species (Agrostis spp.) under controlled environment conditions. Plant Dis. 90:951-956.

Speckled snow mold, caused by Typhula ishikariensis, is one of the most important Typhula snow molds in subarctic zones of the Northern Hemisphere. Nine isolates of three T. ishikariensis varieties (var. ishikariensis, var. canadensis, and var. idahoensis) isolated from infected turfgrasses on golf course fairways throughout Wisconsin were evaluated for their aggressiveness toward nine cultivars of three bentgrass species (three creeping, three colonial, and three velvet cultivars) under controlled environmental conditions. Speckled snow mold severity increased as inoculum concentration of $T$. ishikariensis was increased. In general, bentgrass susceptibility increased between 9 and 11 weeks after seeding but gradually decreased thereafter, suggesting expression of age-related resistance as plants matured. Significant differences in aggressiveness were detected within and among $T$. ishikariensis varieties. Significant interactions between T. ishikariensis varieties or isolates and bentgrass species were detected, but there was no interaction between pathogen isolates and bentgrass cultivars. Disease severity evaluations showed significant differences among bentgrass cultivars and species in their response to $T$. ishikariensis. Since bentgrass species exhibit differential responses to T. ishikariensis varieties, representative isolates of each variety should be employed for screening of bentgrass germplasm for resistance to speckled snow mold.
\end{abstract}

Typhula ishikariensis Imai, the causal agent of speckled snow mold, is an important pathogen of winter cereals and perennial grasses in subarctic zones of the Northern Hemisphere $(14,24,25,28)$. The pathogen has been documented in alfalfa, clover, conifer, timothy, and winter turnip in addition to graminaceous plants $(14,16,28)$. There are three varieties of $T$. ishikariensis: var. ishikariensis, var. canadensis, and var. idahoensis (3). T. ishikariensis var. ishikariensis favors a less fluctuating habitat and has faster growth ability than var. canadensis and var. idahoensis $(7,9,20)$.

Most cool-season turfgrasses, including bentgrass (Agrostis spp.), Kentucky bluegrass (Poa pratensis L.), creeping red fescue (Festuca rubra L.), and perennial ryegrass (Lolium perenne L.) have been reported as hosts of $T$. ishikariensis $(1,25,28)$. Bentgrass species are commonly used on golf course tees, greens, and fairways, and often sustain severe damage from $T$. ishikariensis infections during

Corresponding author: G. Jung

E-mail: jung@plantpath.wisc.edu

Accepted for publication 23 March 2006.

DOI: 10.1094/PD-90-0951

(C) 2006 The American Phytopathological Society winter (15). Of the bentgrass species, creeping (A. stolonifera L.), colonial (A. capillaries L.), velvet (A. canina L.), redtop (A. gigantean L.), and dryland ( $A$. castellana L.), creeping bentgrass is used most frequently for golf course turf, but interest is increasing in the development of colonial and velvet bentgrass varieties for golf course use $(4,26,32)$.

The symptoms of speckled snow mold on turfgrasses appear after snowmelt in late winter or early spring as circular, water-soaked or straw-colored patches. Individual patches are usually less than $1 \mathrm{~m}$ across but can coalesce to form large areas (30). Plants in diseased patches are typically matted, slimy, and covered with mycelium and sclerotia of the pathogen. During the spring thaw, $T$. ishikariensis produces numerous brown or black sclerotia, which serve as oversummering structures and become a source of primary inoculum when temperatures become more favorable for pathogen germination in late fall (15).

The severity of snow mold damage is generally governed by environmental conditions such as temperature, humidity, snow cover duration, and availability of primary inoculum $(5,6,10)$. In particular, snow cover duration and air temperature during winter have the greatest impact on the ecological distribution of Typhula species (9). Extended periods of continuous snow cover and low temperatures reduce the photosynthetic and metabolic rate of the host plants, thereby increasing their susceptibility to infection and colonization by the pathogen (22).

The spatial distribution of T. ishikariensis varieties may be caused by their adaptation to harsh conditions, such as long snow cover period, low temperature, and host nutrient status $(9,19,21)$. T. ishikariensis var. ishikariensis is frequently found in areas with reduced snow cover duration compared to var. canadensis and in areas with lower temperature than the other $T$. ishikariensis varieties (9).

The most environmentally sound means of disease control is through the use of resistant cultivars. Currently, snow mold diseases are managed with a combination of cultural practices and preventative fungicide applications in the fall $(8,33)$. The use of pathogen-resistant cultivars has been limited by our knowledge of the relative susceptibility of bentgrass species and cultivars to snow mold diseases. Characterization of the pathogenic variation within and among $T$. ishikariensis varieties has provided valuable information for breeding programs aimed at improving resistance to speckled snow mold (31). Therefore, in the present study, we examined the effect of inoculum concentration and plant age on the susceptibility of bentgrass species and cultivars by $T$. ishikariensis under controlled environmental conditions, and also evaluated the variation in aggressiveness within and among varieties of $T$. ishikariensis.

\section{MATERIALS AND METHODS}

Plant materials. Four creeping bentgrass cultivars (L-93, Penncross, Pennlinks, and Providence), three colonial bentgrass cultivars (Bardot, SR 7100, and Tiger), and three velvet bentgrass cultivars (Barvaria, Greenwich, and Vesper) were used for this study. Cultivars of creeping and colonial bentgrass ( $0.056 \mathrm{~g}$ of seeds) and velvet cultivars (0.035 $\mathrm{g}$ of seeds) were evenly sown into plastic pots $(5.3 \times$ $5.3 \times 5.1 \mathrm{~cm})$ containing commercial potting soil mixture (Metro Mix 366-P, Scott's Company, Marysville, $\mathrm{OH})$. The plants were grown in the greenhouse at 18 to $28^{\circ} \mathrm{C}$ with light and dark cycle of 16 and 8 $\mathrm{h}$, respectively. The plants were mown weekly with scissors to a height of $0.6 \mathrm{~cm}$ beginning 2 weeks after germination until 
the onset of hardening for acquisition of snow mold resistance of tested plants $(2,13)$. The fertilizer (SunGrow Company, Austin, TX) at 0.02-0.005-0.02 g of actual N-P-K per pot was applied biweekly from 4 weeks after germination to 2 weeks prior to hardening.

Plants were transferred to a controlled environment chamber for hardening 21 days prior to their scheduled inoculation. Hardening conditions were $10^{\circ} \mathrm{C}$ and $10-\mathrm{h}$ day length for 7 days; $5^{\circ} \mathrm{C}$ and 8 -h day length for 7 days; and $2^{\circ} \mathrm{C}$ and 6-h day length for 7 days. The pots were placed into plastic trays containing distilled water to assure constant moisture.

Fungal isolates and inoculum. Three isolates of each of three T. ishikariensis varieties were randomly selected from a collection of isolates previously collected in Wisconsin (Table 1) (9). Inoculum was prepared using a procedure modified from Wang et al. (31). In brief, five 5-mmdiameter plugs were taken from the edge of colonies growing on potato dextrose agar (PDA) and transferred to $20 \mathrm{ml}$ of potato dextrose broth (PDB) in $250-\mathrm{ml}$ flasks and grown for 20 days at $10^{\circ} \mathrm{C} \pm$ $1^{\circ} \mathrm{C}$ with no light. For each isolate, four to six flasks of mycelium were harvested and mixed, then air-dried for 30 min under a laminar flow hood. Residual water in airdried mycelia was finally removed by vacuum-filtration for 3 min under 21 psi (1.5 $\mathrm{kg} / \mathrm{cm}^{2}$ ) of pressure through cheesecloth. Mycelium weights were recorded and the mycelium was homogenized in a blender with sterile distilled water for $30 \mathrm{~s}$. The mycelial suspensions were then adjusted to the desired concentration using sterile distilled water.

Inoculation procedure. Sterile pipettes were used to deliver $1 \mathrm{ml}$ of mycelium suspension directly to the soil surface in the center of each pot. Immediately after inoculation, distilled water was applied to the foliage until runoff with a hand sprayer. Inoculated pots were then arranged in a randomized complete block design in a plastic box $(70 \times 40 \times 15 \mathrm{~cm}$, Rubbermaid, Wooster, $\mathrm{OH}$ ); approximately $30 \%$ of the total volume of the box was filled with moist potting soil (1 soil: 1 distilled water, vol/vol). The box was covered to maintain the high humidity required for disease development and was transferred to a controlled environment chamber maintained at $2^{\circ} \mathrm{C}$ and 0 -h day length for 21 days, $5^{\circ} \mathrm{C}$ and 6-h day length for 7 days, and $10^{\circ} \mathrm{C}$ and 8 -h day length for 10 days. The boxes were completely randomized and arranged in the growth chamber.

Experiment 1 was conducted to evaluate the effect of inoculum concentration on disease development. For this experiment, 11-week-old plants after seeding were inoculated with mycelial suspensions containing $0.1,0.2,0.3$, and $0.4 \mathrm{~g}$ mycelium $/ \mathrm{ml}$ from two $T$. ishikariensis var. ishikariensis isolates (no. 2 and no. 3). Six bentgrass cultivars, L-93, Penncross, Pennlinks, and Providence (creeping), Tiger (colonial), and Greenwich (velvet), were inoculated with each inoculum concentration.

Experiment 2 was conducted to evaluate the effect of plant age on disease development. The same six cultivars used in the first experiment were inoculated 9, 11, 13, and 15 weeks after seeding with a $0.3 \mathrm{~g} / \mathrm{ml}$ mycelial suspension of $T$. ishikariensis var. ishikariensis isolate 3, var. canadensis isolate 4, or var. idahoensis isolate 9 .

Experiment 3 was conducted to evaluate variation in pathogenicity/aggressiveness of nine isolates representing three $T$. ishikariensis varieties (Table 1) and also evaluate the speckled snow mold susceptibility of nine cultivars representing each of three bentgrass species. Creeping bentgrass cultivars L-93, Penncross, and Providence, colonial bentgrass cultivars Bardot, SR7100, and Tiger, and velvet bentgrass cultivars Barvaria, Greenwich, and Vesper were inoculated 15 weeks after seeding using a $0.3-\mathrm{g} / \mathrm{ml}$ mycelial suspension.

Disease evaluation and statistical analysis. Disease severity for all three experiments was assessed at 38 days after inoculation by visually estimating the percentage of pot surface area exhibiting speckled snow mold symptoms. The rating at 38 days postinoculation was chosen based on previous inoculations (unpublished data) because this rating was the most reliable under the infection and colonization conditions used in this study. Data are analyzed using mean values of two runs since no significant difference between the runs $(P<0.01)$ was detected.

All statistical analyses were conducted using general linear models procedure

Table 1. Nine isolates of Typhula ishikariensis varieties tested for aggressiveness on cultivars of creeping, colonial, and velvet bentgrass species and the site of collection

\begin{tabular}{lll}
\hline No. & Classification & Site of collection \\
\hline 1 & T. ishikariensis var. ishikariensis & Lanark Links, WI \\
2 & T. ishikariensis var. ishikariensis & Botten's Green Acres, Douglas, WI \\
3 & T. ishikariensis var. ishikariensis & Spider Lake Golf Resort, Sawyer, WI \\
4 & T. ishikariensis var. canadensis & Botten's Green Acres, Douglas, WI \\
5 & T. ishikariensis var. canadensis & Sioux Creek Golf Course, Barron, WI \\
6 & T. ishikariensis var. canadensis & Tahkodah Hills Golf Course, Bayfield, WI \\
7 & T. ishikariensis var. idahoensis & Four Seasons Golf Course, Marinette, WI \\
8 & T. ishikariensis var. idahoensis & Homestead Golf Course, Wood, WI \\
9 & T. ishikariensis var. idahoensis & Spread Eagle Golf Course, WI \\
\hline
\end{tabular}

(PROC GLM) in SAS 7.1 (27). An analysis of variance was used to evaluate the effects of inoculum concentration or plant age on disease development of four creeping bentgrass cultivars. Mean comparisons were done by using the least significant difference (LSD, $P=0.05$ ).

Speckled snow mold severity for nine cultivars of three bentgrass species inoculated with nine isolates of three $T$. ishikariensis varieties were also analyzed by the ANOVA. Differences among inoculum concentrations, plant ages, or cultivars were compared using Fisher's protected least significant difference (LSD) at $P=$ 0.05 .

For experiment 3 , the source of variation for bentgrass species was partitioned into two orthogonal contrasts: diploid (velvet) versus tetraploid genomes (creeping and colonial), and the two tetraploid genomes (creeping versus colonial) according to the procedures of Steel et al. (29). Specifically, the contrast between diploid and tetraploid genomes was performed in order to test for differences in speckled snow mold reaction between bentgrass species having diploid (velvet with $\mathrm{A}_{1} \mathrm{~A}_{1}$ ) and tetraploid genomes (colonial with $\mathrm{A}_{1} \mathrm{~A}_{1} \mathrm{~A}_{2} \mathrm{~A}_{2}$ and creeping with $\mathrm{A}_{2} \mathrm{~A}_{2} \mathrm{~A}_{3} \mathrm{~A}_{3}$ ) (17). Likewise, the contrast between the two tetraploid genomes served to test for differences between bentgrass species having different tetraploid genomes $\left(\mathrm{A}_{1} \mathrm{~A}_{1} \mathrm{~A}_{2} \mathrm{~A}_{2}\right.$ and $\mathrm{A}_{2} \mathrm{~A}_{2} \mathrm{~A}_{3} \mathrm{~A}_{3}$ ). Cultivars within species comprised the remainder of the variability among the nine cultivars. The method of contrasts was used to partition the interactions of the bentgrass species contrasts with isolates within each $T$. ishikariensis variety. All treatments were assumed to be fixed and blocks were assumed to be random in all ANOVAs (27). Mixed models analysis was used to compute standard errors of least squares treatment means.

\section{RESULTS}

Experiment 1: Effect of inoculum concentration on disease development. Typical symptoms of speckled snow mold, circular and water-soaked infections, were observed on inoculated plants. Initial disease symptoms appeared 2 weeks after inoculation using the highest inoculum concentration $(0.4 \mathrm{~g}$ mycelium $/ \mathrm{ml})$ and 3 weeks after inoculation with the lowest concentration $(0.1 \mathrm{~g}$ mycelium $/ \mathrm{ml})$ ANOVA of disease severity detected a significant inoculum concentration effect (Table 2). Disease severity on bentgrass plants progressively increased as inoculum concentration increased from 0.1 to $0.4 \mathrm{~g}$ mycelium/ml (Fig. 1).

A cultivar effect $(P<0.0001)$ was detected among the four creeping bentgrass cultivars. Overall, 'L-93' creeping bentgrass was the least susceptible to concentrations tested, while 'Pennlinks' was the most susceptible. The disease severity of colonial bentgrass 'Tiger' was similar to 
that of cultivars of creeping bentgrass; however, velvet bentgrass 'Greenwich' was more susceptible than creeping and colonial cultivars. A significant interaction $(P<$ $0.0127)$ between isolates and inoculum concentrations was detected (Table 2).

Experiment 2: Effect of plant age on disease development. Significant effects of plant age, isolate, and cultivar $(P<$ $0.0001)$ and interaction between isolate and plant age within cultivar $(P<0.0001)$ were detected (Table 3 ). Disease severity was greatest at the 11-week-old stage and lowest at the 15-week-old stage (Fig. 2). Interestingly, 9-week-old plants showed reduced disease severity compared with 11-week-old plants. A similar trend was noted in most cultivars of the three bentgrass species (Fig. 2), but was most evident in Penncross and Pennlinks cultivars of creeping bentgrass.

Experiment 3: Aggressiveness of $T$. ishikariensis varieties to bentgrass species. Significant differences $(P<0.0001)$ among varieties of $T$. ishikariensis were detected on nine cultivars of three bentgrass species (Table 4). Isolates of var. ishikariensis were more aggressive than isolates of the other varieties (Fig. 3). In addition, significant interactions such as variety $\times$ creeping and colonial versus velvet cultivars, isolate (variety) $\times$ creeping and colonial versus velvet cultivars, and isolate (variety) $\times$ creeping versus colonial cultivars were observed (Table 4). Var. idahoensis was more aggressive to velvet bentgrass cultivars than to cultivars of the other bentgrass species. Significant differences in aggressiveness were observed among isolates within each $T$. ishikariensis variety (Table 4 and Fig. 3).

Speckled snow mold severity was significantly lower on cultivars of creeping and colonial bentgrasses than on velvet bentgrass, whereas no differences were detected between cultivars of creeping and colonial bentgrass (Table 4 and Fig. 3 ).

\section{DISCUSSION}

In the present study, aggressiveness of isolates of three $T$. ishikariensis varieties was evaluated on cultivars of three bentgrass species under controlled environmental conditions. In the inoculated plants, the mycelium of $T$. ishikariensis invaded the crown tissue and the upper portion of the plants, which resulted in circular, water-soaked patches in the infected plants. The infected plants were matted with mycelium and sclerotia. Eventually, the plants were killed.

All bentgrass cultivars tested were susceptible to T. ishikariensis, with an observation of no hypersensitive reaction, but there was a quantitative variation in susceptibility. These findings support a previous study (31) where the existence of quantitative resistance in creeping bentgrass clones to Typhula species was described. Further, Wang et al. (31) reported
Table 2. Analysis of variance for speckled snow mold severity for four cultivars of creeping bentgrass inoculated with two isolates of Typhula ishikariensis var. ishikariensis at four inoculum concentrations $(0.1,0.2,0.3$, and $0.4 \mathrm{~g}$ mycelium $/ \mathrm{ml})$ under controlled environment conditions

\begin{tabular}{lrcrr}
\hline Source of variation & df & Mean square & $\boldsymbol{F}$ value & $\boldsymbol{P}$ \\
\hline Experiment & 1 & 61.9 & 1.14 & 0.2880 \\
Replication (experiment) & 4 & 87.4 & 1.61 & 0.1757 \\
Isolate & 1 & 317.8 & 5.84 & 0.0169 \\
Inoculum concentration (cultivar) & 12 & $5,815.0$ & 106.81 & $<0.0001$ \\
Cultivar & 3 & 450.0 & 9.18 & $<0.0001$ \\
Isolate $\times$ cultivar & 3 & 69.0 & 1.27 & 0.2877 \\
Isolate $\times$ inoculum concentration (cultivar) & 12 & 121.4 & 2.23 & 0.0127 \\
Error & 155 & 54.4 & & \\
\hline
\end{tabular}

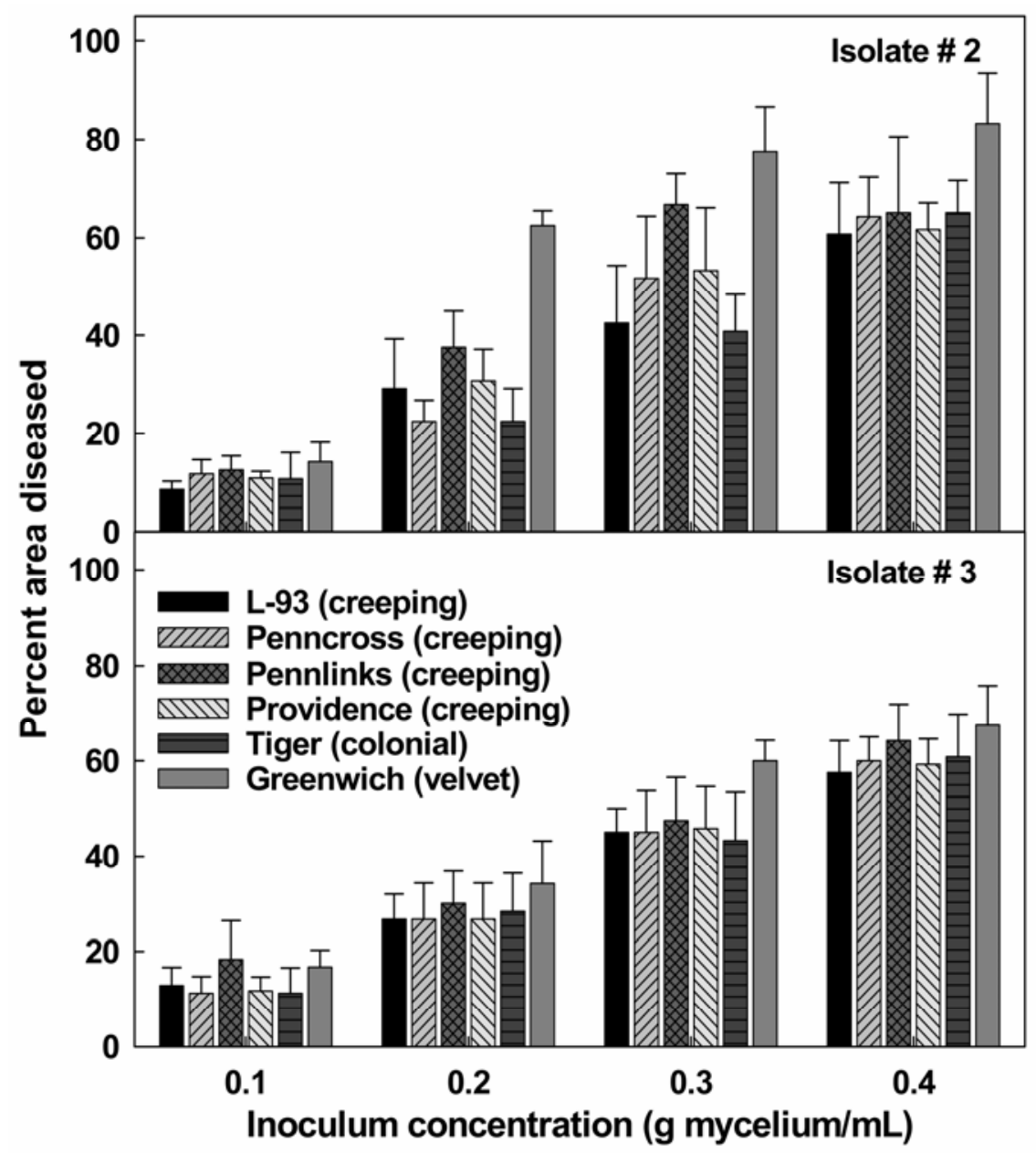

Fig. 1. Disease severity of six cultivars of three bentgrass species inoculated with two isolates of $T y$ phula ishikariensis var. ishikariensis at four inoculum concentrations under controlled conditions. Disease severity was based on mean percent area diseased averaged over three replicates of two experiments. Bars represent standard error of the mean.

Table 3. Analysis of variance for speckled snow mold severity for four cultivars of creeping bentgrass inoculated with three isolates of Typhula ishikariensis at 9, 11, 13, and 15 weeks after seeding under controlled conditions

\begin{tabular}{lrcrr}
\hline Source of variation & df & Mean square & $\boldsymbol{F}$ value & $\boldsymbol{P}$ \\
\hline Experiment & 1 & 215.3 & 1.47 & 0.2262 \\
Replication (experiment) & 4 & 59.3 & 0.41 & 0.8047 \\
Cultivar & 3 & $4,435.7$ & 30.33 & $<0.0001$ \\
Plant age (cultivar) & 12 & $2,850.7$ & 19.49 & $<0.0001$ \\
Isolate & 2 & $5,464.9$ & 37.37 & $<0.0001$ \\
Isolate $\times$ cultivar & 6 & 276.4 & 1.89 & 0.0833 \\
Isolate $\times$ plant age (cultivar) & 24 & 831.7 & 5.69 & $<0.0001$ \\
Error & 235 & 146.2 & &
\end{tabular}




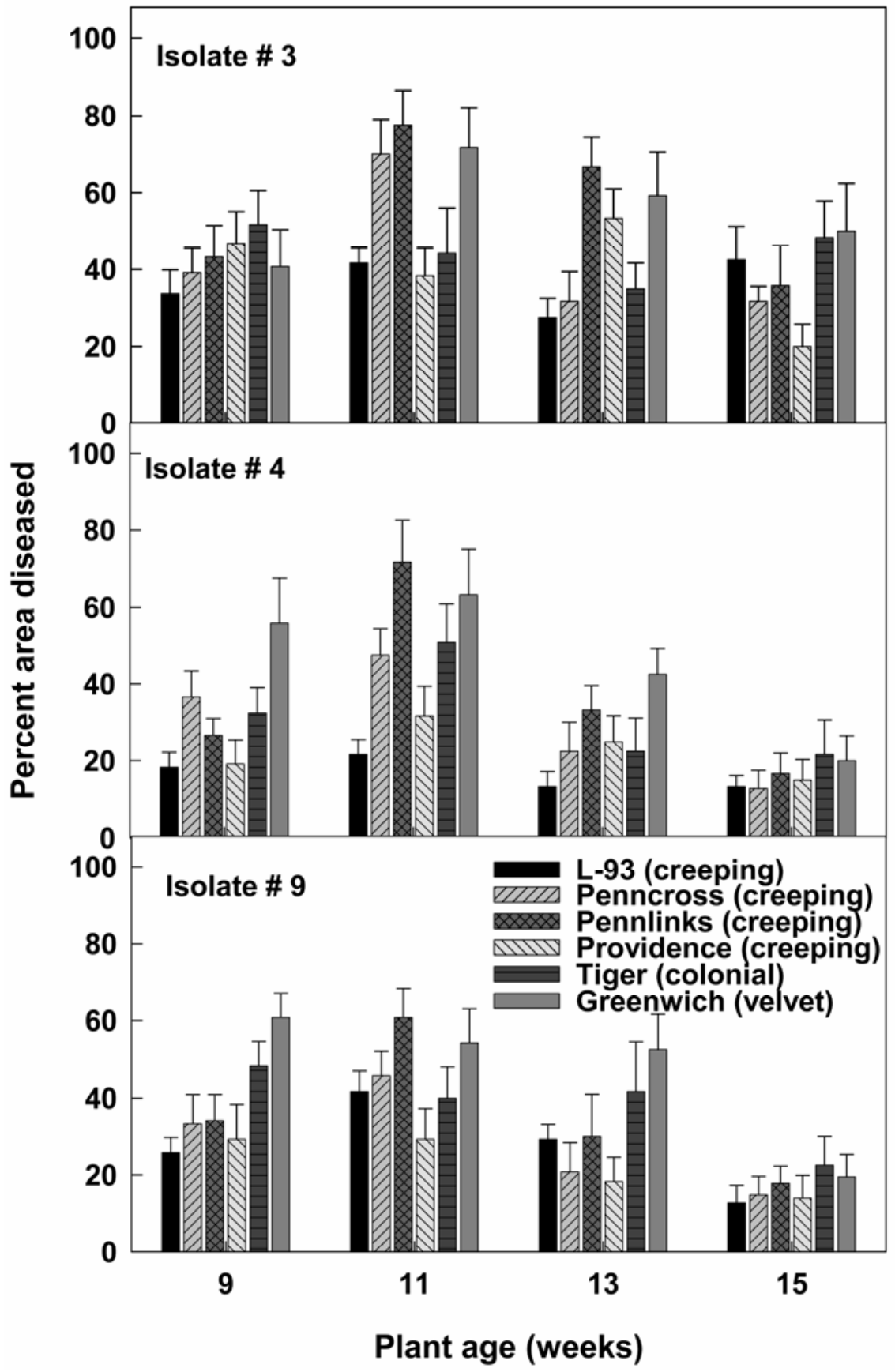

Fig. 2. Disease severity of six cultivars of three bentgrass species inoculated with three isolates of Typhula ishikariensis varieties (isolate 3: var. ishikariensis, isolate 4: var. canadensis, isolate 9: var. idahoensis) at four plant ages $(9,11,13$, and 15 weeks after seeding) under controlled conditions. Disease severity was based on percent area diseased averaged over three replicates of two experiments. Bars represent standard error of the mean.

that Typhula snow mold resistance in clones of creeping bentgrass is a generalized form of resistance, most likely nonrace-specific. This phenomenon also has been recognized in wheat-snow mold pathogen systems $(5,12)$, where snow mold resistance is expressed quantitatively and resistant cultivars exhibit higher survival and yield compared with susceptible cultivars.

Analysis of variance of disease severity showed an interaction effect $(P<0.0127)$ between isolates and inoculum concentrations within cultivar. It is likely due to a plant density that occurs during this time. The significant effect of plant age on disease susceptibility indicated that some cultivars of bentgrasses become less susceptible to speckled snow mold over time. These results indicate that bentgrass plants express age-related resistance to $T$. ishikariensis as they mature, similar to other snow mold pathogen-host interactions $(2,10,11,23)$. Nakajima and Abe (23) reported that older, hardened winter wheat plants were more resistant to snow mold than young plants similarly hardened under controlled conditions. This age-related resistance is believed to be associated with the more rapid accumulation of carbohydrates during hardening and slower metabolization of the carbohydrates in older plants $(5,18,34)$. Therefore, we suggest that 15-week-old bentgrass plants are required for proper screening of speckled snow mold susceptibility under controlled conditions.

The increased susceptibility of 9- to 11week-old bentgrass may be induced by changes in canopy density. Reduced canopy density in immature stands may initially hinder spread of the pathogen from plant to plant. As the stand matures and the canopy becomes more dense, susceptibility may increase until the age-related resistance mechanisms are expressed. The susceptibility of L-93, Providence, and Tiger did not change significantly over the course of 15 weeks. These cultivars may have the capability to express age-related resistance earlier than the cultivars Penncross, Pennlinks, and Greenwich. These cultivars expressing early resistance might be beneficial in the field because it would allow one to plant later in the fall without increasing snow mold susceptibility. Cultivar-dependent snow mold resistance might be enabled at different times during the maturation process, further supporting results of Gaudet et al. (13), which indicated that earlier and higher accumulation of physiologically active substances was involved with snow mold resistance in winter wheat resistant cultivars.

Cultivars of creeping and colonial bentgrasses were less susceptible to $T$. ishikariensis than velvet bentgrass cultivars, and no significant differences were noted between creeping and colonial bentgrass cultivars. This supports the NTEP (National Turfgrass Evaluation Program) data (2001 WI, published online) collected under field conditions, showing that the creeping and colonial bentgrass cultivars were more resistant to snow molds than velvet bentgrass cultivars. It appears that polyploid bentgrass species (creeping with $\mathrm{A}_{2} \mathrm{~A}_{2} \mathrm{~A}_{3} \mathrm{~A}_{3}$ and colonial with $\mathrm{A}_{1} \mathrm{~A}_{1} \mathrm{~A}_{2} \mathrm{~A}_{2}$ genomes) are less susceptible to $T$. ishikariensis than diploid bentgrass species (velvet with $\mathrm{A}_{1} \mathrm{~A}_{1}$ genome). The resistance genes to T. ishikariensis may be contained in the $\mathrm{A}_{2} \mathrm{~A}_{2}$ genome, which is common to creeping and colonial bentgrasses. 
Table 4. Analysis of variance for speckled snow mold severity for nine cultivars of three bentgrass species, creeping, colonial, and velvet, inoculated with nine isolates of three Typhula ishikariensis varieties under controlled conditions

\begin{tabular}{|c|c|c|c|c|}
\hline Source of variation & df & Mean square & $F$ value & $\boldsymbol{P}$ \\
\hline Experiment & 1 & 14.9 & 0.28 & 0.5979 \\
\hline Replication (experiment) & 4 & 100.5 & 1.88 & 0.1125 \\
\hline Variety & 2 & $1,001.4$ & 18.77 & $<0.0001$ \\
\hline Isolates (variety) & 6 & $1,231.1$ & 23.07 & $<0.0001$ \\
\hline Creeping and colonial vs. velvet cultivars & 1 & $18,978.4$ & 355.64 & $<0.0001$ \\
\hline Creeping vs. colonial cultivars & 1 & 13.0 & 0.24 & 0.6213 \\
\hline Cultivar (species) & 6 & 107.2 & 2.01 & 0.0634 \\
\hline Variety $\times$ creeping and colonial vs. velvet cultivars & 2 & $1,705.3$ & 32.00 & $<0.0001$ \\
\hline Variety $\times$ creeping vs. colonial cultivars & 2 & 30.6 & 0.57 & 0.5637 \\
\hline Variety $\times$ cultivar $($ species $)$ & 12 & 57.8 & 1.08 & 0.3724 \\
\hline Isolate (variety) $\times$ creeping and colonial vs. velvet cultivars & 6 & 709.6 & 13.30 & $<0.0001$ \\
\hline Isolate (variety) $\times$ creeping vs. colonial cultivars & 6 & 268.3 & 5.03 & $<0.0001$ \\
\hline Cultivar (species) $\times$ isolate (variety) & 36 & 57.9 & 1.09 & 0.3428 \\
\hline Error & 400 & 53.4 & & \\
\hline
\end{tabular}

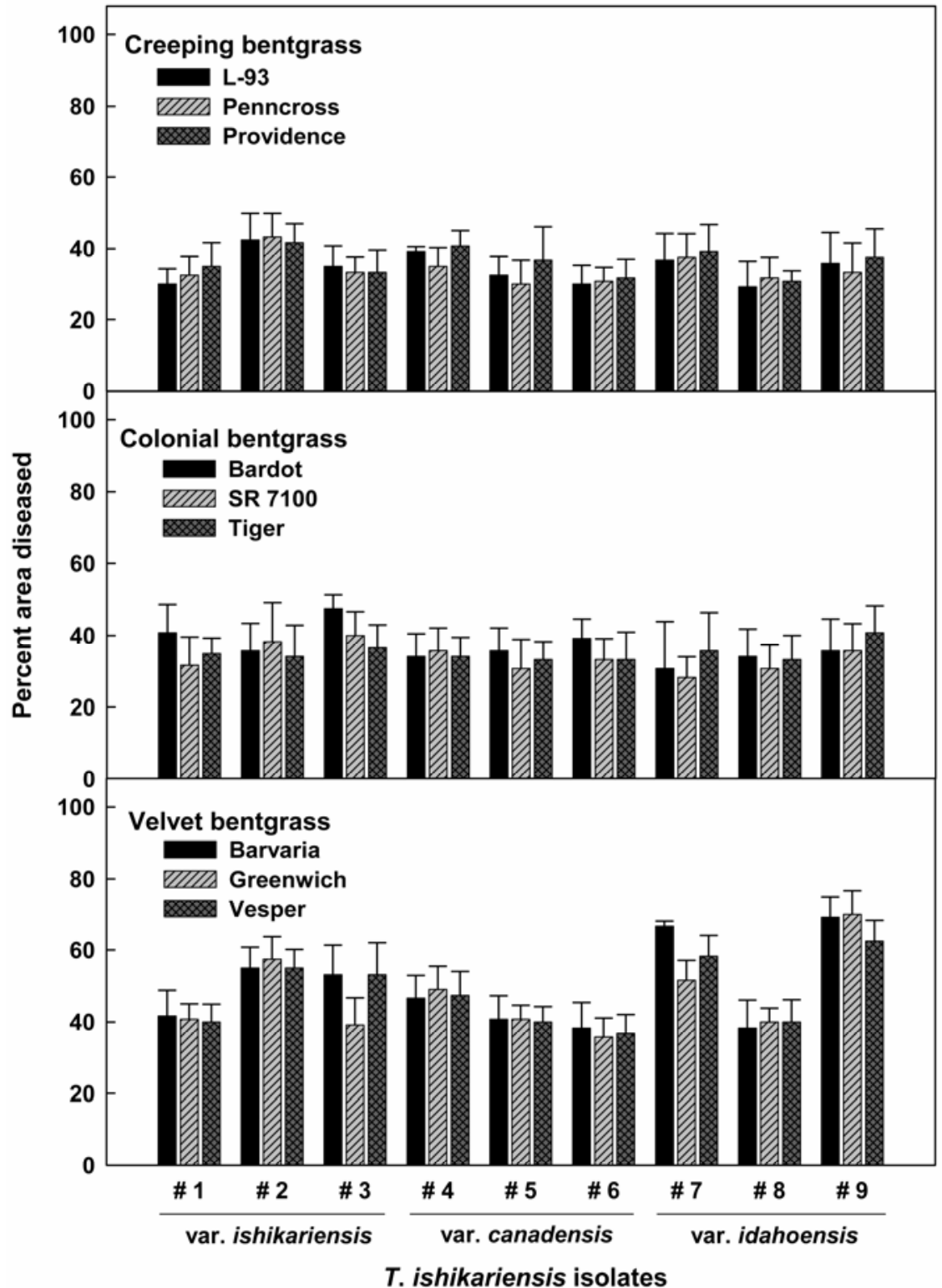

Fig. 3. Disease severity of nine bentgrass cultivars inoculated with three isolates of three Typhula ishikariensis varieties under controlled conditions. Disease severity was based on percent area diseased averaged over three replicates of two experiments. Bars represent standard error of the mean.

Significant differences in aggressiveness among isolates within and among $T$. $i s h i$ kariensis varieties and the lack of isolate and cultivar interaction are very useful information for breeders. This will streamline the process of selecting and breeding Typhula-resistant cultivars within a given bentgrass species because inoculations may be conducted with a single virulent isolate. However, significant interactions between isolates within variety and bentgrass species suggest that a range of isolates representing $T$. ishikariensis varieties should be tested when evaluating clones or cultivars of different bentgrass species.

In summary, when screening for snow mold resistance under growth chamber conditions, inoculum concentration and plant age should be carefully considered. More importantly, varieties and isolates of T. ishikariensis should be selected specifically for each bentgrass species. Further studies under natural field conditions are required to better understand the interactions between isolates of $T$. ishikariensis varieties and bentgrass species.

\section{ACKNOWLEDGMENTS}

We thank Rebecca Abler, Zahi Atallah, and Peter Rogers for their valuable comments and critical review. This work was partly supported by the Postdoctoral Fellowship Program of Korea Science \& Engineering Foundation (KOSEFF) and U.S. Department of Agriculture (USDA) Research Cooperative Agreement.

\section{LITERATURE CITED}

1. Årsvoll, K. 1973. Winter damage in Norwegian grassland, 1968-1971. Meld. Nor. Landbrukshoegsk 52:1-21.

2. Årsvoll, K. 1977. Effect of hardening, plant age, and development in Phleum pratense and Festuca pratensis on resistance to snow mold fungi. Meld. Sci. Rep. Agric. Univ. Norway 56:1-13.

3. Årsvoll, K., and Smith, J. D. 1978. Typhula ishikariensis and its varieties, var. idahoensis comb. nov. and var. canadensis var. nov. Can. J. Bot. 56:348-364.

4. Brilman, L. A. 2003. Velvet bentgrass (Agrostis canina L.). Pages 201-205 in: Turfgrass Biology, Genetics, and Breeding. M. D. Casler and R. R. Duncan, eds. John Wiley \& Sons, Hoboken, NJ.

5. Bruehl, G. W. 1982. Developing wheat resistant to snow mold in Washington State. Plant Dis. 66:1090-1095.

6. Bruehl, G. W., and Cunfer, B. M. 1971. Physiologic and environmental factors that affect the severity of snow mold of wheat. Phytopathology 61:792-799.

7. Bruehl, G. W., and Machtmes, R. 1980. Cultural variation within Typhula idahoensis and T. ishikariensis and the species concept. Phytopathology 70:867-871.

8. Burpee, L. L., Mueller, A. E., and Hannusch, D. J. 1990. Control of Typhula blight and pink 
snow mold of creeping bentgrass and residual suppression of dollarspot by triadimefon and propiconazole. Plant Dis. 74:687-689.

9. Chang, S. W., Scheef, E., Abler, R. A. B., Clayton, M. K., Thomson, S., Johnson, P., and Jung, G. Distribution of Typhula species and $T$. ishikariensis varieties in Wisconsin, Utah, Michigan, and Minnesota. Phytopathology. In press.

10. Gaudet, D. A. 1994. Progress toward understanding interaction between cold hardening and snow mold resistance and development of resistance cultivars. Can. J. Plant Pathol. 16:241-246.

11. Gaudet, D. A., and Chen, T. H. H. 1987. Effects of hardening and plant age on development of resistance to cottony snow mold ( $\mathrm{Co}$ prinus psychromorbidus) in winter wheat under controlled conditions. Can. J. Bot. 65:1152-1156.

12. Gaudet, D. A., and Kozub, G. C. 1991. Screening winter wheat for resistance to cottony snow mold under controlled conditions. Can. Plant Sci. 71:957-965.

13. Gaudet, D. A., Laroche, A., and Yoshida, M. 1999. Low temperature-wheat-fungal interactions: A carbohydrate connection. Physiol. Plant 106:437-444.

14. Hoshino, T., Tkachenko, O. B., Kiriaki, M., Yumoto, I., and Matsumoto, N. 2004. Winter damage caused by Typhula ishikariensis biological species I on conifer seedlings and hop roots collected in the Volga-Ural regions of Russia. Can. J. Plant Pathol. 26:391-396.

15. Hsiang, T., Matsumoto, N., and Millett, S. M. 1999. Biology and management of Typhula snow molds of turfgrass. Plant Dis. 83:788-798.
16. Jamalainen, E. A. 1974. Resistance in winter cereals and grasses to low-temperature parasitic fungi. Annu. Rev. Phytopathol. 12:281302.

17. Jones, K. 1956. Species differentiation in Agrostis, III. A. gigantea Roth. and its hybrids with A. tenuis Sibth. and A. stolonifera L. J. Genet. 54:394-399.

18. Kiyomoto, R. K., and Bruehl, G. W. 1977. Carbohydrate accumulation and deletion by winter cereals differing in resistance to $T y$ phula idahoensis. Phytopathology 67:206-211.

19. Matsumoto, N., and Sato, T. 1983. Niche separation in the pathogenic species of $T y$ phula. Ann. Phytopathol. Soc. Jpn. 49:293298.

20. Matsumoto, N., Sato, T., and Araki, T. 1982. Biotype differentiation in the Typhula ishikariensis complex and their allopathy in Hokkaido. Ann. Phytopathol. Soc. Jpn. 48:275280.

21. Matsumoto, N., and Tajimi, A. 1990. Continuous variation within isolates of Typhula ishikariensis biotypes $\mathrm{B}$ and $\mathrm{C}$ associated with habitat differences. Can. J. Bot. 68:1768-1773.

22. Nakajima, T., and Abe, J. 1994. Development of resistance to Michrodochium nivale in winter wheat during autumn and decline of the resistance under snow. Can. J. Bot. 72:12111215 .

23. Nakajima, T., and Abe, J. 1996. Environmental factors affecting expression of resistance to pink snow mold caused by Microdochium nivale in winter wheat. Can. J. Bot. 74:17831788.

24. Remsberg, R. E. 1940. Studies in the genus Typhula. Mycologia 32:52-96.
25. Remsberg, R. E. 1940. The snow molds of grains and grasses caused by Typhula itoana and Typhula idahoensis. Phytopathology 30:178-180.

26. Ruemmele, B. A. 2003. Agrostis capillaris (Agrostis tenuis Sibth.) colonial bentgrass. Pages 187-200 in: Turfgrass Biology, Genetics, and Breeding. M. D. Casler and R. R. Duncan, ed. John Wiley \& Sons, Hoboken, NJ.

27. SAS Institute Inc. 1999. SAS/STAT User's Guide, Version 7-1. SAS Institute, Cary, NC.

28. Smith, J. D., Jackson, N., and Woolhouse, A. R. 1989. Fungal Diseases of Amenity Turfgrasses. 3rd. ed. E. and F. Spon, London.

29. Steel, R. G. D., Torrie, J. H., and Dickey, D. A. 1996. Principles and Procedures of Statistics: A Biometrical Approach. 3rd ed. McGrawHill, New York.

30. Vargas, J. M., Jr. 1994. Management of turfgrass diseases. CRC Press, Boca Raton, FL.

31. Wang, J., Casler, M. D., Stier, J. C., Gregos, J. S., and Millet, S. M. 2005. Genotypic variations for snow mold reaction among creeping bentgrass clones. Crop Sci. 45:399-406.

32. Warnke, S. 2003. Creeping bentgrass (Agrostis stolonifera L.). Pages 175-185 in: Turfgrass Biology, Genetics, and Breeding. M. D. Casler and R. R. Duncan, ed. John Wiley \& Sons, Hoboken, NJ

33. Worf, G. L. 1988. Evaluating snow mold control. Golf Course Manage. 58:70-80.

34. Yoshida, M., Abe, J., Moriyama, M., Shimokawa, S., and Nakamura, Y. 1997. Seasona changes in the physical state of crown water associated with freezing tolerance in winter wheat. Physiol. Plant 99:363-370. 